\title{
Meeting report from the 2nd International Symposium on New Frontiers in Cardiovascular Research. Protecting the cardiovascular system from ischemia: between bench and bedside
}

\author{
Hector A. Cabrera-Fuentes ${ }^{1,2,3,4,5} \cdot$ Corina Alba-Alba $^{6} \cdot$ Julian Aragones $^{7} \cdot$ Jürgen Bernhagen $^{8}$. \\ William A. Boisvert ${ }^{4,9} \cdot$ Hans E. Bøtker $^{10}$ • Gabriela Cesarman-Maus ${ }^{11} \cdot$ Ingrid Fleming $^{12}$ • \\ David Garcia-Dorado $^{13}$ - Sandrine Lecour ${ }^{14}$ Elisa Liehn ${ }^{15} \cdot$ Michael S. Marber $^{16}$. \\ Nephtali Marina ${ }^{17} \cdot$ Manuel Mayr $^{18}$ - Oscar Perez-Mendez ${ }^{19} \cdot$ Tetsuji Miura $^{20} \cdot$ Marisol Ruiz-Meana $^{13}$. \\ Eduardo M. Salinas-Estefanon ${ }^{21}$ - Sang-Bing Ong,3 $\cdot$ Hans J. Schnittler ${ }^{22}$ • Jose T. Sanchez-Vega ${ }^{23}$. \\ Adriana Sumoza-Toledo $^{24} \cdot$ Carl-Wilhelm Vogel $^{25} \cdot$ Dina Yarullina $^{4} \cdot$ Derek M. Yellon $^{26,27}$. $^{2}$ \\ Klaus T. Preissner ${ }^{1}$ • Derek J. Hausenloy ${ }^{2,3,26,27}$
}

Received: 26 November 2015/Accepted: 26 November 2015/Published online: 14 December 2015

(C) The Author(s) 2015. This article is published with open access at Springerlink.com

\begin{abstract}
Recent advances in basic cardiovascular research as well as their translation into the clinical situation were the focus at the last "New Frontiers in Cardiovascular Research meeting”. Major topics included the characterization of new targets and procedures in
\end{abstract}

Derek J. Hausenloy

derek.hausenloy@duke-nus.edu.sg

1 Institute of Biochemistry, Medical School, Justus-Liebig University, Giessen, Germany

2 Cardiovascular and Metabolic Disorders Program, Duke-National University of Singapore, Singapore, Singapore

3 National Heart Research Institute Singapore, National Heart Centre Singapore, Singapore, Singapore

4 Department of Microbiology, Kazan Federal University, Kazan, Russian Federation

5 Escuela de Ingeniería y Ciencias, Centro de Biotecnología-FEMSA, Tecnológico de Monterrey, Monterrey, NL, México

6 Institute of Genetics, Univeristy of the Sea. Puerto Escondido Campus, Oaxaca Oaxacan System of State Universities (SUNEO), Oaxaca, México

7 Research Unit, Hospital of Santa Cristina, Research Institute Princesa (IP), Autonomous University of Madrid, Madrid, Spain

8 Institute of Biochemistry and Molecular Cell Biology, RWTH Aachen University, Aachen, Germany

9 Center for Cardiovascular Research, John A. Burns School of Medicine, University of Hawaii, Honolulu, USA cardioprotection, deciphering new players and inflammatory mechanisms in ischemic heart disease as well as uncovering microRNAs and other biomarkers as versatile and possibly causal factors in cardiovascular pathogenesis. Although a number of pathological situations such as

10 Department of Cardiology, Aarhus University Hospital, Skejby, Aarhus N, Denmark

11 Department of Hematology, Instituto Nacional de Cancerología, Mexico City, Mexico

12 Institute for Vascular Signalling, Centre for Molecular Medicine, Goethe-University, Frankfurt, Germany

13 Valld'Hebron University Hospital and Research Institute, Barcelona, Spain

14 Hatter Institute and MRC Inter-University Cape Heart Unit, Faculty of Health Sciences, University of Cape Town, Cape Town, South Africa

15 Institute for Molecular Cardiovascular Research, RWTH University Hospital Aachen, Aachen, Germany

16 Department of Cardiology, The Rayne Institute, St Thomas' Campus, King's College London, London, UK

17 Department of Clinical Pharmacology, University College London, London, UK

18 The James Black Centre, King's College, University of London, London, UK

19 Department of Molecular Biology, National Institute of Cardiology, Mexico City, Mexico

20 Department of Cardiovascular, Renal and Metabolic Medicine, Sapporo Medical University School of Medicine, Sapporo, Japan 
ischemia-reperfusion injury or atherosclerosis can be simulated and manipulated in diverse animal models, also to challenge new drugs for intervention, patient studies are the ultimate litmus test to obtain unequivocal information about the validity of biomedical concepts and their application in the clinics. Thus, the open and bidirectional exchange between bench and bedside is crucial to advance the field of ischemic heart disease with a particular emphasis of understanding long-lasting approaches in cardioprotection.

Keywords Atherosclerosis - Cardioprotection . Cardiovascular disease - Endothelial permeability . Extracellular RNA · High-density lipoprotein · Hypoxia · Inflammation · Ischemia/reperfusion injury · Macrophage polarization · MicroRNAs · Mitochondria · Platelet dysfunction · Vascular biology

\section{Introduction}

Ischemic heart disease (IHD) is the leading cause of death and disability worldwide [104]. Thus, new treatment strategies are required to protect the heart from the detrimental effects of acute ischemia/reperfusion injury (IRI) so as to reduce myocardial injury, to preserve left ventricular systolic function, and to prevent the onset of heart failure [40]. During the 2nd International Symposium on "New Frontiers in Cardiovascular Research" (Huatulco-Oaxaca, Mexico), basic researchers and clinicians discussed new biomedical developments as well as novel targets and respective interventional strategies in the areas of heart failure, inflammatory mechanisms, and cardioprotection. In essence, the meeting covered heterogenous and unrelated intra- as well as extracellular molecular targets such as cytokines, ion channels, extracellular nucleic acids, or

21 Laboratorio de Biofísica Cardiaca, Instituto de Fisiología, Universidad Autónoma de Puebla, Puebla, Mexico

22 Institute of Anatomy and Vascular Biology, WestfalianWilhelms-University, Münster, Germany

23 Laboratory of Parasitology, Department of Microbiology and Parasitology, Faculty of Medicine, Universidad Nacional Autónoma de México, Mexico City, Mexico

24 Laboratorio Multidisciplinario de Ciencias Biomédicas, Instituto de Investigaciones Medico-Biológicas, Universidad Veracruzana campus Veracruz, Veracruz, Mexico

25 Department of Pathology, John A. Burns School of Medicine, University of Hawaii, Honolulu, USA

26 The Hatter Cardiovascular Institute, University College London, London, UK

27 The National Institute of Health Research University College London Hospitals Biomedical Research Centre, London, UK mitochondrial factors, which are all linked to the development or prevention of IHD, which not only reflect the complexity of the biological system but also indicate the variety of possible interventional approaches that can be helpful or even lifesaving as a cardioprotective strategy.

\section{The challenges of translating cardioprotection into the clinical setting}

Derek Yellon (UK) opened the meeting by providing an expert overview of cardioprotection from bench-to-bedside with focus given to new therapeutic targets for cardioprotection and the challenges facing the translation of new cardioprotective therapies from the laboratory to the clinical arena; a topic which has been extensively discussed in recent literature, and which has been attributed to a number of factors including the use of inappropriate animal models and poor clinical trial design (reviewed in [27, 29, 33, 52]). In particular, the influence of co-morbidities (e.g., diabetes, hypertension, and hyperlipidemia) and concomitant medication (nitrates, volatile anesthetics, and propofol) on cardioprotection is important factors to take into consideration, especially given the wealth of preclinical data suggesting that these factors confound cardioprotection [20].

The heart can be protected from acute IRI, both experimentally and in the clinical setting, by subjecting it to brief episodes of ischemia and reperfusion, a phenomenon termed "ischemic preconditioning" [72]. However, this manipulation requires an invasive strategy applied directly to the heart and also necessitates that the intervention is applied prior to the index ischemic episode, which of course is not possible in patients presenting with an acute myocardial infarction (MI). Here, the intervention by remote ischemic conditioning (RIC), a noninvasive, lowcost, easily administered cardioprotective procedure, can be applied after the onset of myocardial ischemia and, therefore, has therapeutic potential for patients with STsegment elevation myocardial infarction (STEMI), treating by primary percutaneous coronary intervention (PPCI) [31, 37, 78, 93] or thrombolysis [107]. RIC can be delivered by inflating a standard blood pressure cuff placed on the upper arm or thigh, to induce brief cycles of ischemia and reperfusion to the arm or leg. Whether RIC has the potential to improve short-term clinical outcomes [71, 94, 101] and to prevent long-term major adverse cardiac events in this patient group is currently being investigated by Hans Botker and Derek Hausenloy in the CONDI2/ERIC-PPCI trial, a 4300 STEMI patient international (Denmark, UK, and Spain), multicentre randomized controlled clinical trial by investigating whether RIC can reduce the rates of cardiac death and hospitalization for heart failure at 
12 months (ClinicalTrials.gov Identifiers: NCT01857414 and NCT02342522). Interestingly, Botker's group has found that certain co-morbidities (age, diabetes, hypertension, high body mass index, hyperlipidemia, and left ventricular hypertrophy), and concomitant medications ( $\beta$ blocker, ACE-inhibitor, calcium antagonists, and statins) did not appear to affect the cardioprotective efficacy of RIC in reperfused STEMI patients. Although there is a wealth of preclinical data indicating that co-morbidities and concomitant medication can confound endogenous cardioprotection much of the evidence is restricted to ischemic preconditioning and postconditioning as opposed to remote ischemic conditioning [20].

The results of the recently published ERICCA [28] and RIPHeart [67] multicentre clinical trials have raised the issue of whether concomitant medication can interfere with the cardioprotective effects of RIC in patients undergoing cardiac surgery. In these large clinical outcome studies, RIC using transient arm ischemia/reperfusion was found to have no effect in terms of reducing perioperative myocardial injury or improving short-term or long-term major adverse cardiovascular events. It has been suggested that the use of propofol anesthesia may have, in part, attenuated the cardioprotective effects of RIC in the setting of cardiac surgery $[48,49]$, although the mechanism for this interaction remains unclear and needs to be investigated [38]. The role of propofol in cardioprotection is quite complex and, at times, the data appear inconsistent. A number of experimental studies $[54,59]$ and even one clinical study in cardiac surgery [87] have found propofol to protect the myocardium against acute ischemia/reperfusion injury through an antioxidant effect and inhibition of MPTP opening [42]. Moreover, there is no clear relationship between propofol use and the cardioprotective efficacy of RIPC, with several clinical studies demonstrating RIPC cardioprotection despite the presence of propofol, and others finding no benefit with RIPC, even in the absence of propofol.

\section{Mitochondria as targets for cardioprotection}

Mitochondrial dysfunction lies at the heart of a number of cardiovascular diseases including acute IRI, and treatments aimed at preserving mitochondrial function represent an important cardioprotective strategy for limiting MI size and preserving cardiac function [36]. Glycogen synthase

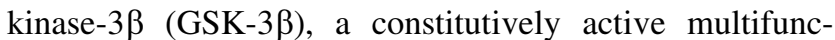
tional kinase, is an important downstream target of a number of pro-survival signaling pathways, recruited by cardioprotective strategies, such as ischemic conditioning, as it contributes to IRI by increasing the susceptibility to mitochondrial permeability transition pore (MPTP) opening [100]. The interplay between GSK-3 $\beta$ and mitochondria in the context of acute myocardial IRI was addressed by Tetsuji Miura (Japan) by showing that the mitochondrial translocation of GSK- $3 \beta$ by oxidant stress appears to be mediated by its kinase-dependent interaction with the voltage-dependent anion channel 2 and that translocated GSK-3 $\beta$ interacted with complex III of the electron transport chain, leading to increased cytotoxic reactive oxygen species (ROS) production [99, 100]. Although the therapeutic inhibition of the mitochondrial translocation of GSK-3 $\beta$ may provide a promising approach to cardioprotection without disturbing the physiological functions of GSK-3 $\beta$, certain co-morbidities such as diabetes, hypertension, and chronic renal failure can disrupt cytoprotective signaling pathways of GSK-3 $\beta$ at different sites, and this may contribute, in part, to the heightened harmful effects of acute myocardial IRI under these medical conditions.

The phenomenon of "mitochondrial dynamics" was introduced by Derek Hausenloy (UK and Singapore) as a novel target for cardioprotection-this refers to the ability of mitochondria to move and change shape by undergoing fission and fusion to generate fragmented and elongated mitochondria, respectively [26, 74, 75]. These processes are required to maintain healthy mitochondria and normal cell function, and their genetic or pharmacological inhibition offer a potential cardioprotective strategy [76]. In particular, the manipulation of mitochondrial fusion proteins such as mitofusin 2 (Mfn2) in the adult heart produced unexpected results in terms of cardioprotection [17]. This fusion protein has been shown to act as a tether between the sarcoplasmic reticulum (SR) and mitochondria [16] and thereby facilitates calcium signaling between these two organelles as a critical step in the coupling of mitochondrial energy production with the energy requirements of the contractile system. Cardiac-specific deletion of the mitochondrial fusion proteins Mfn1 and Mfn2 in the adult murine heart resulted in reduced infarct size when compared to wild-type littermates. This cardioprotective effect appeared to be mediated by the dissociation of the SR from mitochondria, thereby disrupting calcium signaling between both organelles and decreasing mitochondrial calcium overload, attenuating oxidative stress and decreasing MPTP opening. Recent data indicate that the mitochondrial fusion and fission proteins appear to provide therapeutic targets in heart failure, pulmonary hypertension, or cardiomyocyte stem cell differentiation as well [26, 75, 78]. Yet, based upon their pleiotropic functions, manipulation of these mitochondrial fusion and fission proteins needs to be precisely defined in each acute setting in order to prevent detrimental off-target effects such as cardiomyopathy. 
The impact of advanced age on mitochondrial dysfunction, which occurs in the context of acute myocardial IRI, was discussed by Marisol Ruiz-Meana (Spain). Preclinical data have suggested that mitochondria play a causative role in the increased susceptibility of the senescent myocardium to ischemic damage. The existence of an age-dependent disruption of the molecular communication between SR and mitochondria appears to have consequences on calcium handling and bioenergetics in response to acute myocardial IRI [22]. Moreover, oxidation of mitochondrial ATP synthase aggravated mitochondrial membrane permeabilization and cell death in the first minutes of reperfusion [21]; yet, the underlying mechanisms remain to be characterized with regard to the response to injury and cardioprotection in the aging heart, representing a highly relevant topic considering our aging population.

Finally, translating a therapeutic cardioprotective approach that targets mitochondria into the patientś benefit has recently been illustrated with the neutral results of the CIRCUS trial: This trial failed to demonstrate improved clinical outcomes at 1 year (endpoints: cardiac death, heart failure, and adverse left ventricular remodeling) in STEMI patients who received an intravenous bolus of the MPTP inhibitor cyclosporine-A prior to PPCI [14]. Although the reasons for the failure of this trial are not clear, a number of factors should be taken into consideration: (1) Not all experimental studies investigating the infarct-limiting effects of CsA have been positive [44, 60], and the clinical data supporting its cardioprotective effects in STEMI patients have been limited; (2) In the CIRCUS trial, a novel formulation of cyclosporine called CicloMulsion was used, whereas Sandimmune was used in the original study [79]the intralipid carrier vehicle used in CicloMulsion has been reported in experimental studies to be cardioprotective [53], and therefore its presence may have diminished a difference between CsA and vehicle control; (3) Although the initial positive proof-of-concept study only recruited patients treated by direct stenting to ensuring abrupt reperfusion without any angioplasty pre-dilatation [79], the CIRCUS trial also recruited STEMI patients who had not been directly stented [14, 32, 34].

\section{Combination therapy as a cardioprotective strategy}

While several single-target treatment strategies failed to improve clinical outcomes in patients with ischemic heart disease [29, 33, 52], the concept of combination therapy as a potentially more effective approach for preventing myocardial reperfusion injury was introduced by David Garcia-Dorado (Spain). He has investigated the MI- limiting effects of combining ischemic postconditioning with a pharmacological cardioprotective strategy using an in vivo porcine model of acute IRI [83]. Based on the cardioprotective effects of glucagon-like peptide-1 (GLP1) [30] or its analogs (such as exenatide) [61, 103], administered at the onset of reperfusion, their combination with RIC resulted in a significant reduction of infarct size as compared to the individual treatments alone and appeared to be mediated through two distinct pro-survival pathways [4]. In the COMBinAtion Therapy in Myocardial Infarction (COMBAT-MI) trial (ClinicalTrials.gov Identifier: NCT02404376), STEMI patients treated by PPCI will be subjected to this combined therapy, aiming to protect against myocardial infarction and prevent the onset of heart failure.

\section{High-density lipoprotein and cardiovascular disease}

Low levels of high-density lipoprotein (HDL) cholesterol constitute a major risk factor for cardiovascular disease; however, recent therapies aimed at raising HDL levels have failed - the underlying reasons remain unclear. Native and/ or synthetic HDL-subtypes were studied in experimental models of IHD to characterize their possible role in cardioprotection, and Sandrine Lecour (South Africa) reported that HDL subtype 3, containing a high level of sphingosine-1 phosphate, may be superior against acute IRI than HDL subtype 2 [7], indicating that it is the quality of HDL rather than its overall quantity that confers the cardiovascular benefits [84-86].

The close proximity of epicardial adipose tissue toward the media of arteries and its colocalization with atheroma lesions commonly observed in patients submitted to revascularization strongly suggests an active role of epicardial adipose tissue in the genesis and progression of atherosclerosis [63]. Epicardial adipose tissue may thereby act as a paracrine organ in the induction of inflammation and the regulation of the metabolism of vascular smooth muscle cells. Based on clinical studies, the contribution of epicardial adipose tissue and HDL in atheroma calcification of coronary arteries was proposed by Oscar PerezMendez (Mexico) [24]. Here, an altered mRNA-expression of osteopontin, osteonectin, and osteoprotegerin was observed in epicardial adipose tissue obtained from patients with coronary artery disease submitted to revascularization surgery as compared to control individuals who underwent aortic replacement without MI. Since the expression changes of these three genes were clearly associated with the indicated HDL subclasses, a potential role of HDL in the regulation of atheroma calcification appears likely. 


\section{Inflammation in myocardial infarction and subsequent left ventricular remodeling}

Atherosclerosis is a chronic inflammatory disease and is one of the major underlying causes of an acute myocardial infarction [55]. At the meeting, Jürgen Bernhagen (Germany) summarized the wealth of evidence supporting the pro-atherogenic effects of the chemokine-like cytokine macrophage migration-inhibitory factor (MIF) and highlighted emerging novel data reporting its cardioprotective activities in the setting of acute myocardial IRI. His presentation reviewed the distinct mechanistic differences between MIF's pro-atherogenic action in the vasculature (CXCR2/4-mediated leukocyte recruitment, vascular inflammation, and plaque destabilization) versus its cardioprotective action in the ischemic heart (CD74/AMPKand S-nitrosylated MIF-mediated cardioprotection). From a therapeutic perspective, blocking MIF to prevent atherogenesis may adversely block the cardioprotective effect of MIF and should be used with caution. His research group has identified CXCR7 as a novel, fourth, MIF receptor [3, 12]. Finally, further translational considerations were discussed on the role of the broader MIF protein family in clinical outcomes of cardiac surgery patients [96]. Furthermore, upon myocardial infarction, cytokines, such as tumor-necrosis-factor $\alpha$ (TNF- $\alpha)$ as well as alarmins, particularly extracellular RNA (eRNA) become released or liberated from the injured cardiac tissue and represent mediators of acute myocardial IRI [10, 11], as reported by Klaus T. Preissner (Germany). In fact, patients subjected to acute global IRI during cardiac bypass surgery and exhibited significant elevation of plasma eRNA and TNF- $\alpha$ [9]. In experimental models, including in vivo murine myocardial IRI or the isolated Langendorff-perfused rat heart, as well as in cardiomyocytes subjected to hypoxia, eRNA promoted TNF- $\alpha$ liberation through the activation of TNF- $\alpha$ converting enzyme (TACE) [10]. Conversely, TNF$\alpha$ promoted further eRNA release especially under hypoxia, thereby feeding a vicious cell damaging cycle during IRI with the massive production of oxygen radicals, mitochondrial damage, decrease in antioxidant enzymes, and decline of cardiomyocyte functions (unpublished data). The administration of RNase 1 or the TACE-inhibitor TAPI prevented cell death and significantly decreased myocardial infarction. This regimen allowed the reduction in cytokine release, normalization of antioxidant enzymes as well as preservation of cardiac tissue. Finally, a dramatic increase of endogenous vascular RNase1 in human subjects was achieved by inducing remote ischemic preconditioning [37], a noninvasive intermittent limb ischemia and reperfusion using a simple external occluder, thereby proving the impact of the eRNA/RNase system in remote ischemic preconditioning [9].

The left ventricular (LV) remodeling, which takes place following an acute MI, is a critical determinant of final LV systolic function, the onset of heart failure and adverse clinical outcome. In this regard, Elisa Liehn (Germany) discussed the role of immune cells which are able to modify collagen synthesis [56-58] and to activate different signaling pathways in myofibroblasts, with consequences on tissue healing, scar formation, and heart function after an acute MI [15, 43, 89]. In particular, neutrophils activate inflammatory- (TGF-ß1, IL-1ß), differentiation-, migration-, proliferation- and angiogenesis-related genes, thus maintaining a soft cytoskeletal structure, whereas monocytes activate inflammatory- (angiotensin II, NFKB), apoptosis- and remodeling-related genes, thereby increasing the stiffness of the fibroblasts. As a consequence, targeting the extracellular matrix to prevent LV remodeling post-MI appears to be a promising therapeutic approach to provide synergistic benefits with cardiomyocyte-directed therapies.

\section{Cardiac myosin binding protein $\mathrm{C}$ : a novel biomarker for myocardial injury}

The ability to detect the presence of myocardial necrosis in patients presenting with chest pain as a criterion for diagnosing an acute MI depends on the ability to accurately quantify the extent of damage to the myocardium [102]. The use of increasingly sensitive assays for the cardiac forms of Troponin I (cTnI) and Troponin $\mathrm{T}$ (cTnT) has revolutionized the care of patients presenting with suspected non-ST elevation acute coronary syndromes (NSTE-ACS) [70]. However, troponins are released slowly after cardiac injury, and it is therefore necessary to take heed of their exceedingly low concentrations. Consequently, sensitivity is achieved but at the expense of poor specificity [47]. Following a systematic screen of proteins that appeared in the coronary sinus after mild myocardial infarction, Michael Marber (UK) presented the cardiac restricted Cardiac Myosin Binding Protein $\mathrm{C}(\mathrm{cMyC})$ as a potential new biomarker [41] with faster release and clearance kinetics than the troponins [6]. The different dynamics of this novel biomarker would be expected to translate into improved diagnostic performance for the detection of acute MI in NSTE-ACS, a hypothesis which is currently being tested in a large unselected cohort of such patients [25]. 


\section{Cellular adaptation to hypoxia in cardiovascular disease}

Different endogenous adaptive responses to acute IRI in the heart may mobilize as yet unrecognized pathogenetic factors and help to identify novel therapeutic targets for cardioprotection. The hypoxia-inducible factors HIF- $1 \alpha$ and HIF- $2 \alpha$ orchestrate the body's adaptive response to hypoxia (a major component of IRI) through the transcription and translation of several hundred proteins. While HIF- $1 \alpha$ has been suggested as a therapeutic target for cardioprotection [35, 77], little is known about cardiac HIF-2 $\alpha$, which is involved in hypoxic signaling as well. Julian Aragonés (Spain) provided new information on the HIF- $2 \alpha$ isoform, which acts as an mTORC1 activator via the amino acid carrier SLC7A5, especially promoting growth of renal cell carcinoma [19]. While several experimental studies have investigated the tissue protective role of HIF-2 $\alpha$ in the brain [81], kidney [46], or skeletal muscle [5], respective studies in the heart have not been carried out yet. Since ischemia-provoked HIF- $2 \alpha$ activation is essential for the transcription of new proteins that would take some time, therapeutic approaches appear to applicable more towards a delayed cardioprotection rather than to acute protection against IRI.

While hypoxia is known as a stimulus for the increase in sympathetic tone, observed in patients with arterial hypertension, Nephtali Marina (UK) presented evidence that the brainstem in hypertensive animals (spontaneously hypertensive rats, SHR) was relatively hypoxic as well, compared to normotensive Wistar rats [64]. As a consequence, increased levels of "ambient" ATP and lactate in the brainstem of SHR contributed to the development of arterial hypertension by increasing the activity of the pre-sympathetic circuits. Furthermore, it was shown that facilitated breakdown of extracellular ATP-modulated sympathetic activity [65] and attenuated the development of hypertension in SHR [64]. The importance of the Cushing reflex mechanism in the maintenance of adequate oxygen delivery to vital centers of the brain and its role in the pathogenesis of arterial hypertension was indicated as well, demonstrating the importance of glial cells in the regulation of sympathetic activity. Future studies are needed to clarify the metabolic and vascular mechanisms leading to the development of brainstem hypoxia in human subjects with arterial hypertension.

\section{Macrophage polarization as an anti-inflammatory therapeutic strategy}

A variety of inflammatory processes has been shown to initiate and/or sustain molecular processes culminating in CVD [55, 80]. As such, the different steps of the inflammatory cascade as principal mechanism of innate immunity, of host defence and of tissue regeneration may persist or becomes dysregulated, resulting in chronic inflammatory disorders of the cardiovascular system, such a atherosclerosis [69]. In this regard, monocytes/macrophages respond to external stimuli with rapid changes in the expression of numerous inflammation-related genes to undergo polarization towards the M1 (proinflammatory), M2 (anti-inflammatory), or related subphenotypes $[8,13,62]$. Despite the absence of chitin, a polymer of $\beta-\mathrm{N}$-acetyl-glucosamine in mammals [45], the chitin-cleaving glycosyl hydrolase chitotriosidase (Chitinase 1, CHIT1) is abundantly produced and secreted by activated macrophages in association with various human diseases. Importantly, elevated chitinase activity has been found in atherosclerotic lesions [50], and William Boisvert (USA) presented data that indicate a beneficial role for chitinase against vessel degeneration. In particular, the chitinase inhibitor allosamidin was shown to polarize macrophages towards the M1 phenotype to promote inflammation, indicative for the fact that chitinase may play a protective role in the pathogenesis of atherosclerosis by keeping macrophages in the M2 phenotype and promoting lipid uptake and efflux. Further investigations need to clarify the underlying protective mechanisms of chitinase and its possible use as a natural anti-atherogenic drug.

It has been recently shown that eRNA can exert prothrombotic and pro-inflammatory properties in the cardiovascular system and provoke cytokine mobilization as well as macrophage polarization, independent of Toll-like receptor-3 activation [91, 92]. Hector A. Cabrera-Fuentes (Germany and Singapore) demonstrated that mouse bone marrow-derived-macrophages (BMDM), which were differentiated with mouse macrophage-colony-stimulating factor into the M2-phenotype, were found to be skewed toward the inflammatory M1-phenotype when exposed to eRNA [8]. In accordance with the proposed actions of eRNA as a pro-inflammatory "alarm signal" and triggering factor for TACE, these data may shed light on the role of eRNA in the context of chronic inflammatory diseases such as atherosclerosis.

The bi-functional "Transient receptor potential melastatin-2" (TRPM2), which combines a nonselective calcium $\left(\mathrm{Ca}^{2+}\right)$-permeable channel with an adenosine diphosphate ribose pyrohydrolase activity [97], is activated by intracellular adenosine diphosphate ribose and allows both $\mathrm{Ca}^{2+}$ influx into the cell and/or $\mathrm{Ca}^{2+}$ release from lysosomes, contributing to cell migration, cell death, cytokine production, as well as degranulation in monocytes, dendritic cells, neutrophils, and mast cells [51, 73, 97, 98]. Adriana Sumoza-Toledo (Mexico) presented information on cardiac TRPM2, which is involved in inflammatory processes caused by oxidative stress, indicative for a role of 
this channel protein in protection against cardiac IRI [68] as well as for the maintenance of cardiac myocyte bioenergetics [39]. Thus, TRPM2 may also provide a potential target to regulate hyper-inflammatory processes in CVD.

\section{Targeting endothelial permeability as an anti-inflammatory therapeutic strategy}

Endothelial junctional dynamics plays an important role not only in regulating endothelial permeability for a variety of solutes but also in controlling unwanted leukocyte emigration into tissues. A close interaction between the vascular endothelial (VE) -cadherin/catenin complex, the structural and functional backbone of endothelial cell junctions, and actin filament dynamics including actin polymerization and actin/myosin-mediated contractility, simultaneously maintains integrity and dynamics. Due to the lifelong shear stress-dependent biomechanical forces at specific sites of the vascular tree, the affected endothelial cells become continuously stimulated and acquire a dysfunctional phenotype that resembles the inflammatory endothelium. Such chronic conditions are associated with the disturbance of the vascular barrier properties and allow uncontrolled adhesion and transmigration of pro-inflammatory cells into the neointimal region of the inflammatory vessel wall to feed the atherogenic process. To follow the time-related changes and molecular arrangements of endothelial cell junction dynamics, life cell imaging using fluorescent tagged proteins has been very instrumental, as addressed by Hans Schnittler (Münster, Germany). Here, the formation of "Junction associated intermittent lamellipodia" (JAIL) has recently been reported to be one of the key mechanisms that control junction remodeling by largely maintaining cell-junction integrity $[1,2,88]$. JAIL are actin-driven and ARP2/3-N-WASP-controlled small plasma membrane protrusions appearing at gaps between VE-cadherin clusters, such that JAIL form new VE-cadherin adhesion plaques that cluster during JAIL retraction and subsequently become incorporated into the junctions. This process constitutively remodels VE-cadherin patterns and maintains endothelial integrity at the same time. This mechanisms also provides the driving force for cellular motility within a cell monolayer. In response to thrombin as a temporary pro-inflammatory factor, JAIL inhibition occurs with subsequent opening of endothelial cell junctions [90]. Although JAIL has been demonstrated to play a role in angiogenesis and involves the focal contact protein parvin [23], little is known about the relevance of such vascular cell connections in the cardiac macro- or microcirculation both under healthy conditions or in situations of IHD. It remains to be tested whether the identification of distorted cardiac JAIL may serve as marker of dysfunctional vascular endothelium and/or provide new targets for protective interventions.

\section{MicroRNAs, platelet dysfunction, and systems biology approach in cardiovascular research}

Platelets from patients with diabetes are hyper-reactive and demonstrate increased adhesiveness, aggregation, degranulation, and thrombus formation as well as conjugate formation with leukocytes: processes that contribute to the accelerated development of vascular disease. Part of the problem seems to be dysregulated platelet $\mathrm{Ca}^{2+}$ signaling and the activation of intra-platelet calpains, which constitute $\mathrm{Ca}^{2+}$-activated proteases that are required for the limited proteolysis of several substrate proteins and subsequent alterations in platelet signaling. Ingrid Fleming (Germany) has found that the activation of $\mu$ - and m-calpain in patients with type 2 diabetes has profound effects on the platelet proteome and identified septin-5, the integrin-linked kinase (ILK) and Dicer as novel calpain substrates $[18,82]$. The calpain-dependent cleavage of septin5 disturbed its association with syntaxin- 4 and promoted the secretion of $\alpha$-granule contents, including TGF- $\beta$ and the chemokine CCL5. The cleavage of Dicer in platelets from diabetic mice or patients thereby reduced the levels of platelet microRNAs miR-142, miR-143, miR-155, and miR-223. Deletion of miR-223 in mice resulted in modestly enhanced platelet aggregation, the formation of large thrombi, and delayed clot retraction compared to wild-type littermates. A similar dysregulation was detected in platelets from diabetic patients. Proteomic analysis of platelets from miR-223 knockout mice revealed increased levels of several proteins including kindlin-3 and coagulation factor XIII-A: While kindlin-3 was indirectly regulated by miR223, factor XIII was a direct target and both proteins were also altered in diabetic platelets. Most importantly, treating diabetic mice with a calpain inhibitor for only 12 days prevented the loss of platelet Dicer as well as the diabetesinduced decrease in platelet microRNAs and normalized the platelet proteome as well as platelet function. Whether or not the activation of calpain and the subsequent cleavage of Dicer can account for changes in the microRNA profile associated with other diseases remains to be determined.

Finally, Manuel Mayr (UK) provided an overview from a systems biology perspective to help integrate the diverse topics in cardiovascular research for combined technological approaches in finding e.g., new biomarkers or causative relations. This can be achieved using proteomics in combination with other postgenomics technologies, such as lipidomics or microRNA profiling as well the integration of biological information in disease-specific networks for CVD. Unlike genomics, postgenomics approaches are not 
"off-the-shelf technologies" to identify novel biomarker candidates. Rather than evaluating individual biomarkers by routine clinical measurements, the linkage of cuttingedge postgenomics technologies with population studies aims to explore biomarker panels derived from a multiomics approach (proteomics, lipidomics, and microRNAomics) in a primary preventive setting $[66,95,105,106$, 108, 110]. This integration of emerging technologies has the potential to improve our understanding of the etiology, prediction and stratification of CVD. As an primary example, this approach revealed the loss of platelet-related microRNAs in type 2 diabetes and could link a subset of platelet microRNAs (miR-126, miR-223, and miR-197) to cardiovascular risk in the prospective Bruneck study [108110]. Consequently, such bioinformatic information may thus define new pathways where the unraveled molecular connections may be proven by in vitro experiments, by preclinical models as well as in clinical trials.

\section{Summary and conclusions}

In summary, recent advances in cardiovascular research were discussed at this New Frontiers in Cardiovascular Research meeting covering a range of topics including cardioprotection, inflammation research, and vascular biology. A number of novel therapeutic targets for mediating cardiovascular protection in relation to a number of conditions including acute ischemia/reperfusion, heart failure, and atherosclerosis were introduced at the meeting. The important issue of translating new therapeutic strategies from the benchside to the bedside was highlighted given the challenges facing this process - these will have to be improved should we wish to impact on clinical outcomes in our patients with CVD.

Acknowledgments We would like to thank the Rector of SUNEO Modesto Seara Vázquez and to Sandra Karina Ramirez Vasquez, Academic Vice-Rector of Universidad de la Sierra Sur-SUNEO for hosting and in part funding the symposium as well as Alberto Sanchez Lopez, Director of the Consejo Oaxaqueño de Ciencia y Tecnología (COCYT), Oaxaca Convention \& Visitors Bureau "CVB-Oaxaca" (Ministry of Tourism and Economic Development of the state of Oaxaca) and to the authorities of Huatulco-City for their generous support. HACF is funded by a Startup Grant of the "Excellence Cluster Cardio-Pulmonary System" (ECCPS) from the German Research Foundation (DFG, Bonn, Germany) and "Peter und Traudl Engelhorn-Stiftung" (Weilheim, Germany). JA is supported by grants from the Ministerio de Economia y Competitividad (SAF2013-46058R), Red de Cardiovascular (RD12/0042/0065), S2010/BMD-2542 acronimo "Consepoc-CM". JB is funded by DFG grants SFB1123/ A03 and BE 1977/9-1 as well as IZKF Aachen grant K7-1. WAB is funded by NIH grants HL075677 and HL081863. NM is a British Heart Foundation Intermediate Basic Research Fellow (ref. FS/13/5/ 29927). MMarber is supported by grants from the MRC UK (G1000737), Guy's and St Thomas' Charity (R060701, R100404), British Heart Foundation (TG/15/1/31518) and the UK Department of
Health through the National Institute for Health Research Biomedical Research Centre award to Guy's \& St Thomas' National Health Service Foundation Trust. MMayr is a Senior Fellow of the British Heart Foundation (FS/13/2/29892), supported by a British Heart Foundation special project grant (SP/12/5/29574), and the Fondation Leducq Transatlantic Network of Excellence in Cardiovascular Research (MIRVAD; 13 CVD 02), Diabetes UK (12/0004530), and an excellence initiative (Competence Centers for Excellent Technologies-COMET) of the Austrian Research Promotion Agency FFG: "Research Center of Excellence in Vascular Ageing-Tyrol, VASCage" (K-Project number 843536). DGD and MRM are supported by the Instituto de Salud Carlos III (RETICS RIC, RD12/0042/ 0021, PI14/01413, 15/01655 and FIS PI12/00788). HB is supported by the Danish Council for Strategic Research (11-115818), Trygfonden, NovoNordisk Fonden and Fondation Leducq (CVD-06). TM is supported by Grants-in-Aid for Scientific Research from Japan Society for the Promotion of Science (\#23501086, \#26461133). Part of the work presented by HACF and KTP was supported by the "International Research Training Group-1566" of the DFG and the Russian Government Program for competitive growth of Kazan Federal University. DJH is supported by the British Heart Foundation, Rosetrees Trust, and the National Institute for Health Research University College London Hospitals Biomedical Research Centre.

\section{Compliance with ethical standards}

\section{Conflict of interest None.}

Open Access This article is distributed under the terms of the Creative Commons Attribution 4.0 International License (http://crea tivecommons.org/licenses/by/4.0/), which permits unrestricted use, distribution, and reproduction in any medium, provided you give appropriate credit to the original author(s) and the source, provide a link to the Creative Commons license, and indicate if changes were made.

\section{References}

1. Abu Taha A, Schnittler HJ (2014) Dynamics between actin and the VE-cadherin/catenin complex: novel aspects of the ARP2/3 complex in regulation of endothelial junctions. Cell Adhes Migr $8: 125-135$

2. Abu Taha A, Taha M, Seebach J, Schnittler HJ (2014) ARP2/3mediated junction-associated lamellipodia control VE-cadherinbased cell junction dynamics and maintain monolayer integrity. Mol Biol Cell 25:245-256. doi:10.1091/mbc.E13-07-0404

3. Alampour-Rajabi S, El Bounkari O, Rot A, Muller-Newen G, Bachelerie F, Gawaz M, Weber C, Schober A, Bernhagen J (2015) MIF interacts with CXCR7 to promote receptor internalization, ERK1/2 and ZAP-70 signaling, and lymphocyte chemotaxis. FASEB J. doi:10.1096/fj.15-273904

4. Alburquerque-Bejar JJ, Barba I, Inserte J, Miro-Casas E, RuizMeana M, Poncelas M, Vilardosa U, Valls-Lacalle L, Rodriguez-Sinovas A, Garcia-Dorado D (2015) Combination therapy with remote ischaemic conditioning and insulin or exenatide enhances infarct size limitation in pigs. Cardiovasc Res 107:246-254. doi:10.1093/cvr/cvv171

5. Aragones J, Schneider M, Van Geyte K, Fraisl P, Dresselaers T, Mazzone M, Dirkx R, Zacchigna S, Lemieux H, Jeoung NH, Lambrechts D, Bishop T, Lafuste P, Diez-Juan A, Harten SK, Van Noten P, De Bock K, Willam C, Tjwa M, Grosfeld A, Navet R, Moons L, Vandendriessche T, Deroose C, Wijeyekoon B, Nuyts J, Jordan B, Silasi-Mansat R, Lupu F, Dewerchin M, Pugh C, Salmon P, Mortelmans L, Gallez B, Gorus F, Buyse J, 
Sluse F, Harris RA, Gnaiger E, Hespel P, Van Hecke P, Schuit F, Van Veldhoven P, Ratcliffe P, Baes M, Maxwell P, Carmeliet P (2008) Deficiency or inhibition of oxygen sensor Phd1 induces hypoxia tolerance by reprogramming basal metabolism. Nat Genet 40:170-180. doi:10.1038/ng.2007.62

6. Baker JO, Tyther R, Liebetrau C, Clark J, Howarth R, Patterson T, Mollmann H, Nef H, Sicard P, Kailey B, Devaraj R, Redwood SR, Kunst G, Weber E, Marber MS (2015) Cardiac myosinbinding protein $\mathrm{C}$ : a potential early biomarker of myocardial injury. Basic Res Cardiol 110:23. doi:10.1007/s00395-0150478-5

7. Brulhart-Meynet MC, Braunersreuther V, Brinck J, Montecucco F, Prost JC, Thomas A, Galan K, Pelli G, Pedretti S, Vuilleumier N, Mach F, Lecour S, James RW, Frias MA (2015) Improving reconstituted HDL composition for efficient post-ischemic reduction of ischemia reperfusion injury. PLoS One 10:e0119664. doi:10.1371/journal.pone.0119664

8. Cabrera-Fuentes HA, Lopez ML, McCurdy S, Fischer S, Meiler S, Baumer Y, Galuska SP, Preissner KT, Boisvert WA (2015) Regulation of monocyte/macrophage polarisation by extracellular RNA. Thromb Haemost 113:473-481. doi:10.1160/TH1406-0507

9. Cabrera-Fuentes HA, Niemann B, Grieshaber P, Wollbrueck M, Gehron J, Preissner KT, Boning A (2015) RNase1 as a potential mediator of remote ischaemic preconditioning for cardioprotectiondagger. Eur J Cardiothorac Surg. doi:10.1093/ejcts/ ezu519

10. Cabrera-Fuentes HA, Preissner KT (2014) Abstract 20396: induction of ischemia-reperfusion injury by extracellular RNA: a case for tumor necrosis factor (TNF- $\alpha$ ) —-shedding. Circulation 130:A20396

11. Cabrera-Fuentes HA, Ruiz-Meana M, Simsekyilmaz S, Kostin S, Inserte J, Saffarzadeh M, Galuska SP, Vijayan V, Barba I, Barreto G, Fischer S, Lochnit G, Ilinskaya ON, BaumgartVogt E, Boning A, Lecour S, Hausenloy DJ, Liehn EA, Garcia-Dorado D, Schluter KD, Preissner KT (2014) RNase1 prevents the damaging interplay between extracellular RNA and tumour necrosis factor-alpha in cardiac ischaemia/reperfusion injury. Thromb Haemost 112:1110-1119. doi:10.1160/ TH14-08-0703

12. Chatterjee M, Borst O, Walker B, Fotinos A, Vogel S, Seizer P, Mack A, Alampour-Rajabi S, Rath D, Geisler T, Lang F, Langer HF, Bernhagen J, Gawaz M (2014) Macrophage migration inhibitory factor limits activation-induced apoptosis of platelets via CXCR7-dependent Akt signaling. Circ Res 115:939-949. doi:10.1161/CIRCRESAHA.115.305171

13. Cochain C, Zernecke A (2015) Macrophages and immune cells in atherosclerosis: recent advances and novel concepts. Basic Res Cardiol 110:34. doi:10.1007/s00395-015-0491-8

14. Cung TT, Morel O, Cayla G, Rioufol G, Garcia-Dorado D, Angoulvant D, Bonnefoy-Cudraz E, Guerin P, Elbaz M, Delarche N, Coste P, Vanzetto G, Metge M, Aupetit JF, Jouve B, Motreff P, Tron C, Labeque JN, Steg PG, Cottin Y, Range G, Clerc J, Claeys MJ, Coussement P, Prunier F, Moulin F, Roth O, Belle L, Dubois P, Barragan P, Gilard M, Piot C, Colin P, De Poli F, Morice MC, Ider O, Dubois-Rande JL, Unterseeh T, Le Breton H, Beard T, Blanchard D, Grollier G, Malquarti V, Staat P, Sudre A, Elmer E, Hansson MJ, Bergerot C, Boussaha I, Jossan C, Derumeaux G, Mewton N, Ovize M (2015) Cyclosporine before PCI in patients with acute myocardial infarction. N Engl J Med 373:1021-1031. doi:10.1056/NEJMoa1505489

15. Curaj A, Staudt M, Fatu R, Kraaijeveld AO, Jankowski J, Biessen EAL, Liehn EA (2015) Blockade of CCR3 retains the neutrophils, preserving their survival during healing after myocardial infarction. Discoveries 3:e45. doi:10.15190/d.2015. 37
16. de Brito OM, Scorrano L (2008) Mitofusin 2 tethers endoplasmic reticulum to mitochondria. Nature 456:605-610. doi:10. 1038/nature07534

17. de Brito OM, Scorrano L (2008) Mitofusin 2: a mitochondriashaping protein with signaling roles beyond fusion. Antioxid Redox Signal 10:621-633. doi:10.1089/ars.2007.1934

18. Elgheznawy A, Shi L, Hu J, Wittig I, Laban H, Pircher J, Mann A, Provost P, Randriamboavonjy V, Fleming I (2015) Dicer cleavage by calpain determines platelet microRNA levels and function in diabetes. Circ Res 117:157-165. doi:10.1161/CIR CRESAHA.117.305784

19. Elorza A, Soro-Arnaiz I, Melendez-Rodriguez F, RodriguezVaello V, Marsboom G, de Carcer G, Acosta-Iborra B, Albacete-Albacete L, Ordonez A, Serrano-Oviedo L, Gimenez-Bachs JM, Vara-Vega A, Salinas A, Sanchez-Prieto R, Martin del Rio R, Sanchez-Madrid F, Malumbres M, Landazuri MO, Aragones J (2012) HIF2alpha acts as an mTORC1 activator through the amino acid carrier SLC7A5. Mol Cell 48:681-691. doi:10.1016/ j.molcel.2012.09.017

20. Ferdinandy P, Hausenloy DJ, Heusch G, Baxter GF, Schulz R (2014) Interaction of risk factors, comorbidities, and comedications with ischemia/reperfusion injury and cardioprotection by preconditioning, postconditioning, and remote conditioning. Pharmacol Rev 66:1142-1174. doi:10.1124/pr.113.008300

21. Fernandez-Sanz C, Ruiz-Meana M, Castellano J, Miro-Casas E, Nunez E, Inserte J, Vazquez J, Garcia-Dorado D (2015) Altered FoF1 ATP synthase and susceptibility to mitochondrial permeability transition pore during ischaemia and reperfusion in aging cardiomyocytes. Thromb Haemost 113:441-451. doi:10.1160/ TH14-10-0901

22. Fernandez-Sanz C, Ruiz-Meana M, Miro-Casas E, Nunez E, Castellano J, Loureiro M, Barba I, Poncelas M, Rodriguez-Sinovas A, Vazquez J, Garcia-Dorado D (2014) Defective sarcoplasmic reticulum-mitochondria calcium exchange in aged mouse myocardium. Cell Death Dis 5:e1573. doi:10.1038/cddis. 2014.526

23. Fraccaroli A, Pitter B, Taha AA, Seebach J, Huveneers S, Kirsch J, Casaroli-Marano RP, Zahler S, Pohl U, Gerhardt H, Schnittler HJ, Montanez E (2015) Endothelial alpha-parvin controls integrity of developing vasculature and is required for maintenance of cell-cell junctions. Circ Res 117:29-40. doi:10.1161/ CIRCRESAHA.117.305818

24. Garcia-Sanchez C, Posadas-Romero C, Posadas-Sanchez R, Carreon-Torres E, Rodriguez-Perez JM, Juarez-Rojas JG, Martinez-Sanchez C, Fragoso JM, Gonzalez-Pacheco H, VargasAlarcon G, Perez-Mendez O (2015) Low concentrations of phospholipids and plasma HDL cholesterol subclasses in asymptomatic subjects with high coronary calcium scores. Atherosclerosis 238:250-255. doi:10.1016/j.atherosclerosis. 2014.12.004

25. Giannitsis E, Katus HA (2015) A long way to translation: will cMyC survive? Basic Res Cardiol 110:479. doi:10.1007/s00395015-0479-4

26. Hall AR, Burke N, Dongworth RK, Hausenloy DJ (2014) Mitochondrial fusion and fission proteins: novel therapeutic targets for combating cardiovascular disease. Br J Pharmacol 171:1890-1906. doi:10.1111/bph. 12516

27. Hausenloy DJ, Baxter G, Bell R, Botker HE, Davidson SM, Downey J, Heusch G, Kitakaze M, Lecour S, Mentzer R, Mocanu MM, Ovize M, Schulz R, Shannon R, Walker M, Walkinshaw G, Yellon DM (2010) Translating novel strategies for cardioprotection: the hatter workshop recommendations. Basic Res Cardiol 105:677-686. doi:10.1007/s00395-010-0121-4

28. Hausenloy DJ, Candilio L, Evans R, Ariti C, Jenkins DP, Kolvekar S, Knight R, Kunst G, Laing C, Nicholas J, Pepper J, Robertson S, Xenou M, Clayton T, Yellon DM, Investigators ET 
(2015) Remote ischemic preconditioning and outcomes of cardiac surgery. N Engl J Med 373:1408-1417. doi:10.1056/ NEJMoa1413534

29. Hausenloy DJ, Erik Botker H, Condorelli G, Ferdinandy P, Garcia-Dorado D, Heusch G, Lecour S, van Laake LW, Madonna R, Ruiz-Meana M, Schulz R, Sluijter JP, Yellon DM, Ovize M (2013) Translating cardioprotection for patient benefit: position paper from the Working Group of Cellular Biology of the Heart of the European Society of Cardiology. Cardiovasc Res 98:7-27. doi:10.1093/cvr/cvt004

30. Hausenloy DJ, Yellon DM (2008) GLP-1 therapy: beyond glucose control. Circ Heart Fail 1:147-149. doi:10.1161/CIR CHEARTFAILURE.108.810887

31. Hausenloy DJ, Yellon DM (2008) Remote ischaemic preconditioning: underlying mechanisms and clinical application. Cardiovasc Res 79:377-386. doi:10.1093/cvr/cvn114

32. Hausenloy DJ, Yellon DM (2015) Targeting myocardial reperfusion injury-the search continues. $N$ Engl $J$ Med 373:1073-1075. doi:10.1056/NEJMe1509718

33. Heusch G (2013) Cardioprotection: chances and challenges of its translation to the clinic. Lancet 381:166-175. doi:10.1016/ S0140-6736(12)60916-7

34. Heusch G (2015) CIRCUS: a kiss of death for cardioprotection? Cardiovasc Res 108:215-216. doi:10.1093/cvr/cvv225

35. Heusch G (2012) HIF-1alpha and paradoxical phenomena in cardioprotection. Cardiovasc Res 96:214-215. doi:10.1093/cvr/ cvs145 (discussion 216-219)

36. Heusch G (2015) Molecular basis of cardioprotection: signal transduction in ischemic pre-, post-, and remote conditioning. Circ Res 116:674-699. doi:10.1161/CIRCRESAHA.116.305348

37. Heusch G, Botker HE, Przyklenk K, Redington A, Yellon D (2015) Remote ischemic conditioning. J Am Coll Cardiol 65:177-195. doi:10.1016/j.jacc.2014.10.031

38. Heusch G, Gersh BJ (2015) ERICCA and RIPHeart: two nails in the coffin for cardioprotection by remote ischemic conditioning? Probably not! Eur Heart J. doi:10.1093/eurheartj/ ehv606

39. Hoffman NE, Miller BA, Wang J, Elrod JW, Rajan S, Gao E, Song J, Zhang XQ, Hirschler-Laszkiewicz I, Shanmughapriya S, Koch WJ, Feldman AM, Madesh M, Cheung JY (2015) $\mathrm{Ca}(2)(+)$ entry via Trpm2 is essential for cardiac myocyte bioenergetics maintenance. Am J Physiol Heart Circ Physiol 308:H637-H650. doi:10.1152/ajpheart.00720.2014

40. Ibanez B, Heusch G, Ovize M, Van de Werf F (2015) Evolving therapies for myocardial ischemia/reperfusion injury. J Am Coll Cardiol 65:1454-1471. doi:10.1016/j.jacc.2015.02.032

41. Jacquet S, Yin X, Sicard P, Clark J, Kanaganayagam GS, Mayr M, Marber MS (2009) Identification of cardiac myosin-binding protein $\mathrm{C}$ as a candidate biomarker of myocardial infarction by proteomics analysis. Mol Cell Proteomics 8:2687-2699. doi:10. 1074/mcp.M900176-MCP200

42. Javadov SA, Lim KH, Kerr PM, Suleiman MS, Angelini GD, Halestrap AP (2000) Protection of hearts from reperfusion injury by propofol is associated with inhibition of the mitochondrial permeability transition. Cardiovasc Res 45:360-369

43. Kanzler I, Tuchscheerer N, Steffens G, Simsekyilmaz S, Konschalla S, Kroh A, Simons D, Asare Y, Schober A, Bucala R, Weber C, Bernhagen J, Liehn EA (2013) Differential roles of angiogenic chemokines in endothelial progenitor cell-induced angiogenesis. Basic Res Cardiol 108:310. doi:10.1007/s00395012-0310-4

44. Karlsson LO, Zhou AX, Larsson E, Astrom-Olsson K, Mansson C, Akyurek LM, Grip L (2010) Cyclosporine does not reduce myocardial infarct size in a porcine ischemia-reperfusion model. J Cardiovasc Pharmacol Ther 15:182-189. doi:10.1177/ 1074248410362074
45. Kitamoto S, Egashira K, Ichiki T, Han X, McCurdy S, Sakuda S, Sunagawa K, Boisvert WA (2013) Chitinase inhibition promotes atherosclerosis in hyperlipidemic mice. Am $\mathrm{J}$ Pathol 183:313-325. doi:10.1016/j.ajpath.2013.04.003

46. Kojima I, Tanaka T, Inagi R, Kato H, Yamashita T, Sakiyama A, Ohneda O, Takeda N, Sata M, Miyata T, Fujita T, Nangaku M (2007) Protective role of hypoxia-inducible factor-2alpha against ischemic damage and oxidative stress in the kidney. J Am Soc Nephrol 18:1218-1226. doi:10.1681/ASN.2006060639

47. Korley FK, Jaffe AS (2013) Preparing the United States for high-sensitivity cardiac troponin assays. J Am Coll Cardiol 61:1753-1758. doi:10.1016/j.jacc.2012.09.069

48. Kottenberg E, Musiolik J, Thielmann M, Jakob H, Peters J, Heusch G (2014) Interference of propofol with signal transducer and activator of transcription 5 activation and cardioprotection by remote ischemic preconditioning during coronary artery bypass grafting. J Thorac Cardiovasc Surg 147:376-382. doi:10. 1016/j.jtcvs.2013.01.005

49. Kottenberg E, Thielmann M, Bergmann L, Heine T, Jakob H, Heusch G, Peters J (2012) Protection by remote ischemic preconditioning during coronary artery bypass graft surgery with isoflurane but not propofol-a clinical trial. Acta Anaesthesiol Scand 56:30-38. doi:10.1111/j.1399-6576.2011.02585.x

50. Kzhyshkowska J, Gratchev A, Goerdt S (2007) Human chitinases and chitinase-like proteins as indicators for inflammation and cancer. Biomark Insights 2:128-146

51. Lange I, Yamamoto S, Partida-Sanchez S, Mori Y, Fleig A, Penner R (2009) TRPM2 functions as a lysosomal Ca2+-release channel in beta cells. Sci Signal 2:ra23. doi:10.1126/scisignal. 2000278

52. Lecour S, Botker HE, Condorelli G, Davidson SM, GarciaDorado D, Engel FB, Ferdinandy P, Heusch G, Madonna R, Ovize M, Ruiz-Meana M, Schulz R, Sluijter JP, Van Laake LW, Yellon DM, Hausenloy DJ (2014) ESC working group cellular biology of the heart: position paper: improving the preclinical assessment of novel cardioprotective therapies. Cardiovasc Res 104:399-411. doi:10.1093/cvr/cvu225

53. Li J, Iorga A, Sharma S, Youn JY, Partow-Navid R, Umar S, Cai H, Rahman S, Eghbali M (2012) Intralipid, a clinically safe compound, protects the heart against ischemia-reperfusion injury more efficiently than cyclosporine-A. Anesthesiology 117:836-846. doi:10.1097/ALN.0b013e3182655e73

54. Li W, Zhang Y, Liu Y, Yue F, Lu Y, Qiu H, Gao D, Gao Y, Wu Y, Wang Z, Huang R, Zhang C (2012) In vitro kinetic evaluation of the free radical scavenging ability of propofol. Anesthesiology 116:1258-1266. doi:10.1097/ALN.0b013e3182567dcc

55. Liehn EA, Cabrera-Fuentes HA (2015) Inflammation between defense and disease: impact on tissue repair and chronic sickness. Discoveries 3(1):e42. doi:10.15190/d.2015.34

56. Liehn EA, Piccinini AM, Koenen RR, Soehnlein O, Adage T, Fatu R, Curaj A, Popescu A, Zernecke A, Kungl AJ, Weber C (2010) A new monocyte chemotactic protein-1/chemokine CC motif ligand-2 competitor limiting neointima formation and myocardial ischemia/reperfusion injury in mice. J Am Coll Cardiol 56:1847-1857. doi:10.1016/j.jacc.2010.04.066

57. Liehn EA, Postea O, Curaj A, Marx N (2011) Repair after myocardial infarction, between fantasy and reality: the role of chemokines. J Am Coll Cardiol 58:2357-2362. doi:10.1016/j. jacc.2011.08.034

58. Liehn EA, Tuchscheerer N, Kanzler I, Drechsler M, Fraemohs L, Schuh A, Koenen RR, Zander S, Soehnlein O, Hristov M, Grigorescu G, Urs AO, Leabu M, Bucur I, Merx MW, Zernecke A, Ehling J, Gremse F, Lammers T, Kiessling F, Bernhagen J, Schober A, Weber C (2011) Double-edged role of the CXCL12/ CXCR4 axis in experimental myocardial infarction. J Am Coll Cardiol 58:2415-2423. doi:10.1016/j.jacc.2011.08.033 
59. Lim KH, Halestrap AP, Angelini GD, Suleiman MS (2005) Propofol is cardioprotective in a clinically relevant model of normothermic blood cardioplegic arrest and cardiopulmonary bypass. Exp Biol Med (Maywood) 230:413-420

60. Lim WY, Messow CM, Berry C (2012) Cyclosporin variably and inconsistently reduces infarct size in experimental models of reperfused myocardial infarction: a systematic review and metaanalysis. Br J Pharmacol 165:2034-2043. doi:10.1111/j.14765381.2011.01691.x

61. Lonborg J, Vejlstrup N, Kelbaek H, Botker HE, Kim WY, Mathiasen AB, Jorgensen E, Helqvist S, Saunamaki K, Clemmensen P, Holmvang L, Thuesen L, Krusell LR, Jensen JS, Kober L, Treiman M, Holst JJ, Engstrom T (2012) Exenatide reduces reperfusion injury in patients with ST-segment elevation myocardial infarction. Eur Heart J 33:1491-1499. doi:10.1093/ eurheartj/ehr309

62. Lopez ML, Bruges G, Crespo G, Salazar V, Deglesne PA, Schneider H, Cabrera-Fuentes H, Schmitz ML, Preissner KT (2014) Thrombin selectively induces transcription of genes in human monocytes involved in inflammation and wound healing. Thromb Haemost 112:992-1001. doi:10.1160/TH14-01-0034

63. Luna-Luna M, Medina-Urrutia A, Vargas-Alarcon G, CossRovirosa F, Vargas-Barron J, Perez-Mendez O (2015) Adipose tissue in metabolic syndrome: onset and progression of atherosclerosis. Arch Med Res 46:392-407. doi:10.1016/j. arcmed.2015.05.007

64. Marina N, Ang R, Machhada A, Kasymov V, Karagiannis A, Hosford PS, Mosienko V, Teschemacher AG, Vihko P, Paton JF, Kasparov S, Gourine AV (2015) Brainstem hypoxia contributes to the development of hypertension in the spontaneously hypertensive rat. Hypertension 65:775-783. doi:10.1161/ HYPERTENSIONAHA.114.04683

65. Marina N, Tang F, Figueiredo M, Mastitskaya S, Kasimov V, Mohamed-Ali V, Roloff E, Teschemacher AG, Gourine AV, Kasparov S (2013) Purinergic signalling in the rostral ventrolateral medulla controls sympathetic drive and contributes to the progression of heart failure following myocardial infarction in rats. Basic Res Cardiol 108:317. doi:10.1007/s00395-012-0317-

66. Mayr M, Zampetaki A, Willeit P, Willeit J, Kiechl S (2013) MicroRNAs within the continuum of postgenomics biomarker discovery. Arterioscler Thromb Vasc Biol 33:206-214. doi:10. 1161/ATVBAHA.112.300141

67. Meybohm P, Bein B, Brosteanu O, Cremer J, Gruenewald M, Stoppe C, Coburn M, Schaelte G, Boning A, Niemann B, Roesner J, Kletzin F, Strouhal U, Reyher C, Laufenberg-Feldmann R, Ferner M, Brandes IF, Bauer M, Stehr SN, Kortgen A, Wittmann M, Baumgarten G, Meyer-Treschan T, Kienbaum P, Heringlake M, Schon J, Sander M, Treskatsch S, Smul T, Wolwender E, Schilling T, Fuernau G, Hasenclever D, Zacharowski K, Collaborators RIS (2015) A multicenter trial of remote ischemic preconditioning for heart surgery. $\mathrm{N}$ Engl $\mathrm{J}$ Med 373:1397-1407. doi:10.1056/NEJMoa1413579

68. Miller BA, Hoffman NE, Merali S, Zhang XQ, Wang J, Rajan S, Shanmughapriya S, Gao E, Barrero CA, Mallilankaraman K, Song J, Gu T, Hirschler-Laszkiewicz I, Koch WJ, Feldman AM, Madesh M, Cheung JY (2014) TRPM2 channels protect against cardiac ischemia-reperfusion injury: role of mitochondria. J Biol Chem 289:7615-7629. doi:10.1074/jbc.M113.533851

69. Moss JW, Ramji DP (2015) Interferon-gamma: promising therapeutic target in atherosclerosis. World $\mathrm{J}$ Exp Med 5:154-159. doi:10.5493/wjem.v5.i3.154

70. Mueller C (2014) Biomarkers and acute coronary syndromes: an update. Eur Heart J 35:552-556. doi:10.1093/eurheartj/eht530

71. Munk K, Andersen NH, Schmidt MR, Nielsen SS, Terkelsen CJ, Sloth E, Botker HE, Nielsen TT, Poulsen SH (2010) Remote ischemic conditioning in patients with myocardial infarction treated with primary angioplasty: impact on left ventricular function assessed by comprehensive echocardiography and gated single-photon emission CT. Circ Cardiovasc Imaging 3:656-662. doi:10.1161/CIRCIMAGING.110.957340

72. Murry CE, Jennings RB, Reimer KA (1986) Preconditioning with ischemia: a delay of lethal cell injury in ischemic myocardium. Circulation 74:1124-1136

73. Oda S, Uchida K, Wang X, Lee J, Shimada Y, Tominaga M, Kadowaki M (2013) TRPM2 contributes to antigen-stimulated $\mathrm{Ca}(2)(+)$ influx in mucosal mast cells. Pflugers Arch 465:1023-1030. doi:10.1007/s00424-013-1219-y

74. Ong SB, Dongworth RK, Cabrera-Fuentes HA, Hausenloy DJ (2015) Role of the MPTP in conditioning the heart-translatability and mechanism. Br J Pharmacol 172:2074-2084. doi:10. 1111/bph.13013

75. Ong SB, Kalkhoran SB, Cabrera-Fuentes HA, Hausenloy DJ (2015) Mitochondrial fusion and fission proteins as novel therapeutic targets for treating cardiovascular disease. Eur J Pharmacol 763:104-114. doi:10.1016/j.ejphar.2015.04.056

76. Ong SB, Subrayan S, Lim SY, Yellon DM, Davidson SM, Hausenloy DJ (2010) Inhibiting mitochondrial fission protects the heart against ischemia/reperfusion injury. Circulation 121:2012-2022. doi:10.1161/CIRCULATIONAHA.109.906610

77. Ong SG, Lee WH, Theodorou L, Kodo K, Lim SY, Shukla DH, Briston T, Kiriakidis S, Ashcroft M, Davidson SM, Maxwell PH, Yellon DM, Hausenloy DJ (2014) HIF-1 reduces ischaemiareperfusion injury in the heart by targeting the mitochondrial permeability transition pore. Cardiovasc Res 104:24-36. doi:10. 1093/cvr/cvu172

78. Pickard JM, Botker HE, Crimi G, Davidson B, Davidson SM, Dutka D, Ferdinandy P, Ganske R, Garcia-Dorado D, Giricz Z, Gourine AV, Heusch G, Kharbanda R, Kleinbongard P, MacAllister R, McIntyre C, Meybohm P, Prunier F, Redington A, Robertson NJ, Suleiman MS, Vanezis A, Walsh S, Yellon DM, Hausenloy DJ (2015) Remote ischemic conditioning: from experimental observation to clinical application: report from the 8th Biennial Hatter Cardiovascular Institute Workshop. Basic Res Cardiol 110:453. doi:10.1007/s00395-014-0453-6

79. Piot C, Croisille P, Staat P, Thibault H, Rioufol G, Mewton N, Elbelghiti R, Cung TT, Bonnefoy E, Angoulvant D, Macia C, Raczka F, Sportouch C, Gahide G, Finet G, Andre-Fouet X, Revel D, Kirkorian G, Monassier JP, Derumeaux G, Ovize M (2008) Effect of cyclosporine on reperfusion injury in acute myocardial infarction. N Engl J Med 359:473-481. doi:10.1056/ NEJMoa071142

80. Preissner KT, Boisvert WA, Hausenloy DJ (2015) Surfing on the cardiovascular frontier wave. Thromb Haemost 113:439-440. doi:10.1160/TH15-01-0086

81. Ralph GS, Parham S, Lee SR, Beard GL, Craigon MH, Ward N, White JR, Barber RD, Rayner W, Kingsman SM, Mundy CR, Mazarakis ND, Krige D (2004) Identification of potential stroke targets by lentiviral vector mediated overexpression of HIF-1 alpha and HIF-2 alpha in a primary neuronal model of hypoxia. J Cereb Blood Flow Metab 24:245-258. doi:10.1097/01.WCB. 0000110532.48786 .46

82. Randriamboavonjy V, Isaak J, Elgheznawy A, Pistrosch F, Fromel T, Yin X, Badenhoop K, Heide H, Mayr M, Fleming I (2012) Calpain inhibition stabilizes the platelet proteome and reactivity in diabetes. Blood 120:415-423. doi:10.1182/blood2011-12-399980

83. Rodriguez-Sinovas A, Cabestrero A, Garcia del Blanco B, Inserte J, Garcia A, Garcia-Dorado D (2009) Intracoronary acid infusion as an alternative to ischemic postconditioning in pigs. Basic Res Cardiol 104:761-771. doi:10.1007/s00395-009-0032- 
84. Sattler K, Graler M, Keul P, Weske S, Reimann CM, Jindrova H, Kleinbongard P, Sabbadini R, Brocker-Preuss M, Erbel R, Heusch G, Levkau B (2015) Defects of high-density lipoproteins in coronary artery disease caused by low sphingosine-1-phosphate content: correction by sphingosine-1-phosphate-loading. J Am Coll Cardiol 66:1470-1485. doi:10.1016/j.jacc.2015.07. 057

85. Sattler KJ, Elbasan S, Keul P, Elter-Schulz M, Bode C, Graler MH, Brocker-Preuss M, Budde T, Erbel R, Heusch G, Levkau B (2010) Sphingosine 1-phosphate levels in plasma and HDL are altered in coronary artery disease. Basic Res Cardiol 105:821-832. doi:10.1007/s00395-010-0112-5

86. Sattler KJ, Herrmann J, Yun S, Lehmann N, Wang Z, Heusch G, Sack S, Erbel R, Levkau B (2009) High high-density lipoprotein-cholesterol reduces risk and extent of percutaneous coronary intervention-related myocardial infarction and improves long-term outcome in patients undergoing elective percutaneous coronary intervention. Eur Heart J 30:1894-1902. doi:10.1093/ eurheartj/ehp183

87. Sayin MM, Ozatamer O, Tasoz R, Kilinc K, Unal N (2002) Propofol attenuates myocardial lipid peroxidation during coronary artery bypass grafting surgery. Br J Anaesth 89:242-246

88. Schnittler H, Taha M, Schnittler MO, Taha AA, Lindemann N, Seebach J (2014) Actin filament dynamics and endothelial cell junctions: the Ying and Yang between stabilization and motion. Cell Tissue Res 355:529-543. doi:10.1007/s00441-014-1856-2

89. Schuh A, Butzbach B, Curaj A, Simsekyilmaz S, Bucur O, Kanzler I, Denecke B, Konschalla S, Kroh A, Sönmez TT, Marx N, Liehn EA (2014) Novel insights into the mechanism of cellbased therapy after chronic myocardial infarction. Discoveries $1: e 9$

90. Seebach J, Taha AA, Lenk J, Lindemann N, Jiang X, Brinkmann K, Bogdan S, Schnittler HJ (2015) The cell border tracker, a novel tool to quantitatively analyze spatiotemporal endothelial junction dynamics at the subcellular level. Histochem Cell Biol. doi:10.1007/s00418-015-1357-8

91. Simsekyilmaz S, Cabrera-Fuentes HA, Meiler S, Kostin S, Baumer Y, Liehn EA, Weber C, Boisvert WA, Preissner KT, Zernecke A (2014) Response to letter regarding article "role of extracellular RNA in atherosclerotic plaque formation in mice". Circulation 130:e144-e145. doi:10.1161/CIRCULATIONAHA. 114.012346

92. Simsekyilmaz S, Cabrera-Fuentes HA, Meiler S, Kostin S, Baumer Y, Liehn EA, Weber C, Boisvert WA, Preissner KT, Zernecke A (2014) Role of extracellular RNA in atherosclerotic plaque formation in mice. Circulation 129:598-606. doi:10. 1161/CIRCULATIONAHA. 113.002562

93. Sivaraman V, Pickard JM, Hausenloy DJ (2015) Remote ischaemic conditioning: cardiac protection from afar. Anaesthesia 70:732-748. doi:10.1111/anae.12973

94. Sloth AD, Schmidt MR, Munk K, Kharbanda RK, Redington AN, Schmidt M, Pedersen L, Sorensen HT, Botker HE, Investigators C (2014) Improved long-term clinical outcomes in patients with ST-elevation myocardial infarction undergoing remote ischaemic conditioning as an adjunct to primary percutaneous coronary intervention. Eur Heart J 35:168-175. doi:10. 1093/eurheartj/eht369

95. Stegemann C, Pechlaner R, Willeit P, Langley SR, Mangino M, Mayr U, Menni C, Moayyeri A, Santer P, Rungger G, Spector TD, Willeit J, Kiechl S, Mayr M (2014) Lipidomics profiling and risk of cardiovascular disease in the prospective populationbased Bruneck study. Circulation 129:1821-1831. doi:10.1161/ CIRCULATIONAHA.113.002500

96. Stoppe C, Rex S, Goetzenich A, Kraemer S, Emontzpohl C, Soppert J, Averdunk L, Sun Y, Rossaint R, Lue H, Huang C, Song Y, Pantouris G, Lolis E, Leng L, Schulte W, Bucala R,
Weber C, Bernhagen J (2015) Interaction of MIF family proteins in myocardial ischemia/reperfusion damage and their influence on clinical outcome of cardiac surgery patients. Antioxid Redox Signal. doi:10.1089/ars.2014.6243

97. Sumoza-Toledo A, Lange I, Cortado H, Bhagat H, Mori Y, Fleig A, Penner R, Partida-Sanchez S (2011) Dendritic cell maturation and chemotaxis is regulated by TRPM2-mediated lysosomal Ca2+ release. FASEB J 25:3529-3542. doi:10.1096/fj.10178483

98. Sumoza-Toledo A, Penner R (2011) TRPM2: a multifunctional ion channel for calcium signalling. J Physiol 589:1515-1525. doi:10.1113/jphysiol.2010.201855

99. Sunaga D, Tanno M, Kuno A, Ishikawa S, Ogasawara M, Yano T, Miki T, Miura T (2014) Accelerated recovery of mitochondrial membrane potential by GSK-3beta inactivation affords cardiomyocytes protection from oxidant-induced necrosis. PLoS One 9:e112529. doi:10.1371/journal.pone.0112529

100. Tanno M, Kuno A, Ishikawa S, Miki T, Kouzu H, Yano T, Murase H, Tobisawa T, Ogasawara M, Horio Y, Miura T (2014) Translocation of glycogen synthase kinase-3beta (GSK-3beta), a trigger of permeability transition, is kinase activity-dependent and mediated by interaction with voltage-dependent anion channel 2 (VDAC2). J Biol Chem 289:29285-29296. doi:10. 1074/jbc.M114.563924

101. Thielmann M, Kottenberg E, Kleinbongard P, Wendt D, Gedik N, Pasa S, Price V, Tsagakis K, Neuhauser M, Peters J, Jakob H, Heusch G (2013) Cardioprotective and prognostic effects of remote ischaemic preconditioning in patients undergoing coronary artery bypass surgery: a single-centre randomised, doubleblind, controlled trial. Lancet 382:597-604. doi:10.1016/S0140 6736(13)61450-6

102. Thygesen K, Alpert JS, Jaffe AS, Simoons ML, Chaitman BR, White HD, Joint ESCAAHAWHFTFftUDoMI, Katus HA, Lindahl B, Morrow DA, Clemmensen PM, Johanson P, Hod H, Underwood R, Bax JJ, Bonow RO, Pinto F, Gibbons RJ, Fox KA, Atar D, Newby LK, Galvani M, Hamm CW, Uretsky BF, Steg PG, Wijns W, Bassand JP, Menasche P, Ravkilde J, Ohman EM, Antman EM, Wallentin LC, Armstrong PW, Simoons ML, Januzzi JL, Nieminen MS, Gheorghiade M, Filippatos G, Luepker RV, Fortmann SP, Rosamond WD, Levy D, Wood D, Smith SC, Hu D, Lopez-Sendon JL, Robertson RM, Weaver D, Tendera M, Bove AA, Parkhomenko AN, Vasilieva EJ, Mendis S (2012) Third universal definition of myocardial infarction. Circulation 126:2020-2035. doi:10.1161/CIR.0b013e31826e1058

103. Timmers L, Henriques JP, de Kleijn DP, Devries JH, Kemperman H, Steendijk P, Verlaan CW, Kerver M, Piek JJ, Doevendans PA, Pasterkamp G, Hoefer IE (2009) Exenatide reduces infarct size and improves cardiac function in a porcine model of ischemia and reperfusion injury. J Am Coll Cardiol 53:501-510. doi:10.1016/j.jacc.2008.10.033

104. WHO (2015) Cardiovascular diseases (CVDs). Fact Sheet 317. In: World Health Organisation. Available from: URL: http:// www.who.int/mediacentre/factsheets/fs317/en/

105. Willeit P, Kiechl S, Kronenberg F, Witztum JL, Santer P, Mayr M, Xu Q, Mayr A, Willeit J, Tsimikas S (2014) Discrimination and net reclassification of cardiovascular risk with lipoprotein(a): prospective 15-year outcomes in the Bruneck Study. J Am Coll Cardiol 64:851-860. doi:10.1016/j.jacc.2014.03.061

106. Willeit P, Zampetaki A, Dudek K, Kaudewitz D, King A, Kirkby NS, Crosby-Nwaobi R, Prokopi M, Drozdov I, Langley SR, Sivaprasad S, Markus HS, Mitchell JA, Warner TD, Kiechl S, Mayr M (2013) Circulating microRNAs as novel biomarkers for platelet activation. Circ Res 112:595-600. doi:10.1161/CIR CRESAHA.111.300539

107. Yellon DM, Ackbarkhan AK, Balgobin V, Bulluck H, Deelchand A, Dhuny MR, Domah N, Gaoneadry D, Jagessur RK, 
Joonas N, Kowlessur S, Lutchoo J, Nicholas JM, Pauvaday K, Shamloll O, Walker JM, Hausenloy DJ (2015) Remote ischemic conditioning reduces myocardial infarct size in STEMI patients treated by thrombolysis. J Am Coll Cardiol 65:2764-2765. doi:10.1016/j.jacc.2015.02.082

108. Zampetaki A, Kiechl S, Drozdov I, Willeit P, Mayr U, Prokopi M, Mayr A, Weger S, Oberhollenzer F, Bonora E, Shah A, Willeit J, Mayr M (2010) Plasma microRNA profiling reveals loss of endothelial miR-126 and other microRNAs in type 2 diabetes. Circ Res 107:810-817. doi:10.1161/CIRCRESAHA. 110.226357
109. Zampetaki A, Mayr M (2015) Sweet dicer: impairment of micro-RNA processing by diabetes. Circ Res 117:116-118. doi:10.1161/CIRCRESAHA.117.306817

110. Zampetaki A, Willeit P, Tilling L, Drozdov I, Prokopi M, Renard JM, Mayr A, Weger S, Schett G, Shah A, Boulanger CM, Willeit J, Chowienczyk PJ, Kiechl S, Mayr M (2012) Prospective study on circulating MicroRNAs and risk of myocardial infarction. J Am Coll Cardiol 60:290-299. doi:10. 1016/j.jacc.2012.03.056 